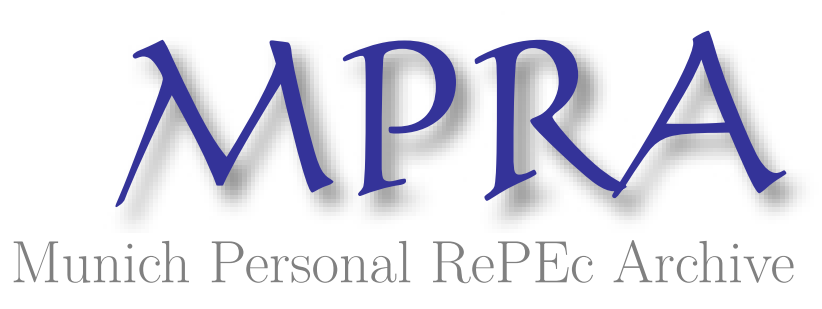

\title{
The Impact of Real Effective Exchange Rate on the Non-oil Export: The Case of Azerbaijan
}

Fakhri, Hasanov

Institute for Scientific Research on Economic Reforms, Ministry of Economic Development of the Republic of Azerbaijan

2010

Online at https://mpra.ub.uni-muenchen.de/29556/

MPRA Paper No. 29556, posted 16 Mar 2011 20:10 UTC 


\title{
The Impact of Real Exchange Rate on Non-Oil Exports: The case of Azerbaijan
}

\author{
Fakhri Hasanov ${ }^{1}$ and Ilaha Samadova ${ }^{2}$
}

\begin{abstract}
The paper investigates the impact of the real exchange rate on non-oil exports in Azerbaijan by applying Vector Error Correction Model.

The estimation results suggest that real exchange rate has negative impact on non-oil export performance while non-oil GDP affects positively in the long-and short-run. Error correction term indicates that short-run fluctuation can be adjusted into long-run equilibrium relationship.

Based on findings of the study can be concluded that appreciating real exchange rate is one of major factors that impede non-oil export growth.

Since promotion of non-oil export is one of the urgent issues of the strategic economic policy of Azerbaijan Republic then findings of this study may be useful for policymakers.
\end{abstract}

JEL Codes: C32, F31, F41, O24, P28

Keywords: Azerbaijani economy, Non-oil export, Real effective exchange rate, Non-oil GDP, Dutch Disease, Vector Error Correction Model.

\footnotetext{
${ }^{1} \mathrm{PhD}$ from Azerbaijan State Economic University. Deputy Director at Institute for Scientific Research on Economic Reforms under Ministry of Economic Development. Senior scientific worker at Institute of Cybernetics, Azerbaijan National Academy of Sciences. Baku, Azerbaijan. E-mail: fakhri.hasanov@gmail.com. Tel.: (+99412) 43017 17. Fax: (+99412) 4300215. I am thankful to Mr. Hendrik Hagedorn for his valuable comments and suggestions.

${ }^{2}$ Senior specialist. Institute for Scientific Research on Economic Reforms under the Ministry of Economic Development. ilahe_semedova@hotmail.com
} 


\section{Content}

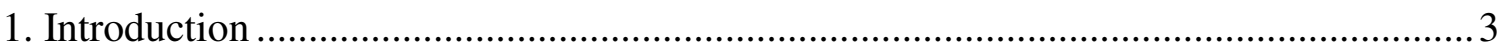

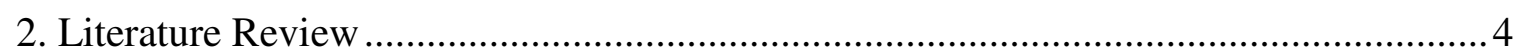

3. Data collection, Non-oil Export Equation and Employing methodology ...................... 7

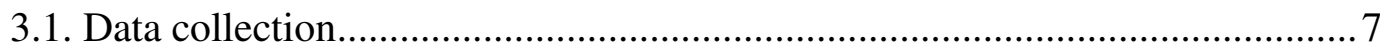

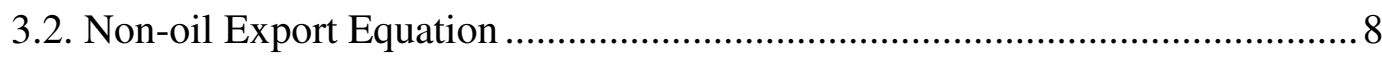

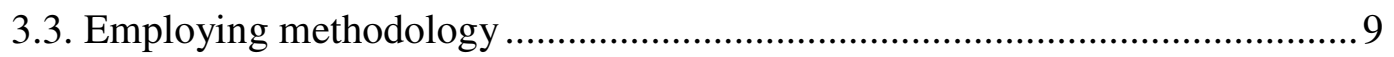

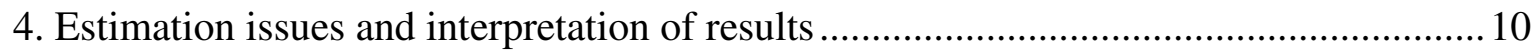

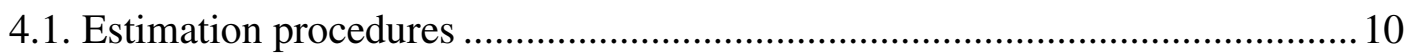

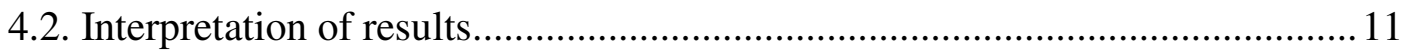

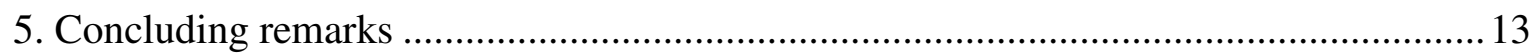

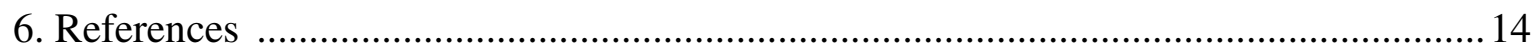

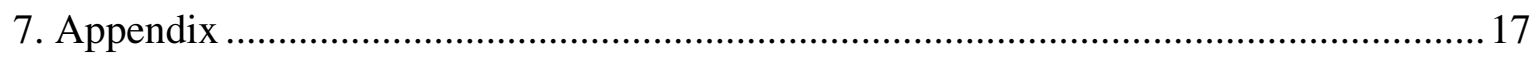




\section{Introduction}

Export earnings assume vital importance not only for developing, but also for developed countries. Developed countries mainly export capital and final goods, while the main part of export of developing countries consists of mining-industry goods especially natural resources. According to export-led growth hypothesis increased export can perform the role of "engine of economic growth" because it can increase employment, create profit, trigger greater productivity and lead to rise in accumulation of reserves allowing a country to balance their finances (Emilio (2001), Goldstein and Pevehouse (2008), Gibson and Michael (1992), McCombie and Thirlwall (1994)). In this context there are some challenges for countries with natural resource abundance such as oil in comparison with other countries. The main point is that in parallel with windfall of oil revenues these countries have to pay more attention to the development of the non-oil sector as well as its export performance (Sorsa, 1999)). Because in the most of the cases oil driven economic development leads to some undesirable consequences such as Dutch Disease in the oil rich countries.

In this regard Dutch Disease concept provides certain link between the real exchange rate and non-oil export. According to this concept the appreciation of a country's real exchange rate caused by the sharp rise in export of a booming resource sector draws capital and labour away from a country's manufacturing and agricultural sectors, which can lead to a decline in exports of agricultural and manufactured goods and inflate the price of non-tradable goods (Corden (1982) and Corden and Nearly (1984)). If we divide overall export of oil rich countries into oil and non-oil exports appreciation of real exchange rate which is specific for these countries negatively affects non-oil exports while export revenues of oil sector mainly depends on oil price in the world markets.

Above stated problem is also specific for Azerbaijan, one of the oil rich countries. According to official statistics the volume of non-oil export has decreased by 26.5 percent between 2004 and 2008 while appreciation of the real effective exchange rate has approximately doubled in the same period ${ }^{3}$. On the other hand, the share of non-oil export in the total export has decreased from 52.5 percent in

\footnotetext{
${ }^{3}$ Statistical bulletin of Central Bank of Azerbaijan, 2008
} 
2004 to 4.7 percent in 2008 . These facts indicate the worsening of non-oil export performance and urgency for its promotion.

The main objective of this study is to analyze the impact of changes in the real exchange rate on the export performance of the non-oil sector and to suggest policy proposals which may be useful for policymakers in non-oil export promotion issues.

This study finds that appreciating exchange rate is one of the major factors that impede non-oil export growth while increase in value added of non-oil sector leads to raise in non-oil export earnings in Azerbaijan.

The study can contribute to existing empirical literature by investigating the influence of the exchange rate on non-oil exports in Azerbaijan. The rest of the paper is organized as following. Literature review section consists of reviewed relevant literatures, while Data collection, Non-oil Export Equation and Employing methodology section describes non-oil export equation, required data and underlying methodology. Estimation issues and interpretation of results section covers the estimations' outputs and interpretations of them. Concluding remarks section summarizes main findings of the study. Reviewed literatures are listed in the Reference section and estimation outputs mainly are placed in Appendix.

\section{Literature Review}

There is huge number of studies that investigate the impact of exchange rate on export. But according to our research objective we try mainly to focus on studies that investigate this relationship in case of oil dependent economies like Azerbaijan.

Bernardina (2004) investigates impacts of the real exchange rate, real non-oil GDP, and the world income on Russian non-oil export by using an Error Correction Model over the period 1994-2001. Author finds that there is a robust and negative long run co-integration relationship between the real exchange rate and Russian non-oil exports. Furthermore, the world income has positive effect on Russian non-oil export while real non-oil GDP causes a decline in non-oil export. 
By using Static OLS and Fix Effect based on Two Stage LS Masoud and Rastegari (2008) estimate effects of certain factors as well as real exchange rate on non-oil export over the period 1995-2005. Study concludes that Iran's non-oil exports positively related to increase in population, per capita income and consumer price index while negatively depends on appreciation of real exchange rate.

Another study related to Iranian non-oil export comes from Sabuhi and Piri (2008). They explore the effects of exchange rate, export volume, domestic saffron production on price of saffron, Iran's major non-oil export good in the short- and long-run. Employing Autoregressive Distributed Lag (ARDL) model shows that appreciating exchange rate has statistically significant negative impact on export price of saffron while there is no significant relationship between export price and domestic production of Saffron in the long-run.

Sorsa (1999) analyzes Algerian non-oil export promotion issues in presence of oil sector dominancy over the period 1981-1997 and reveals that appreciation of real exchange rate is the major factor that impedes non-oil export growth and its diversification.

The effects of real exchange rate, its movements and volatility on the growth of non-oil export in Nigeria are studied by Ogun (1998) over the period 1960-1990. The results show that real exchange rate and also both its misalignment and volatility affect non-oil export growth adversely.

Oyejide (1986) examines effects of trade and exchange rate policies on Nigeria's agricultural export using Ordinary Least Squares (OLS) over the period 1960-1982 and concludes that appreciation of real exchange rate adversely influences to non-oil export especially during the oil boom.

Another study that investigates relationship between exchange rate and non-oil export goods in Nigeria comes from Yusuf and Edom (2007). By applying Johansen co-integration approach over the period 1970-2003 they reveal that depreciation of official exchange rate promotes export of round wood and sawn wood in Nigeria.

Adubi and Okunmadewa (1999) investigate impact of exchange rate and price indexes and also their volatilities on the agricultural export of Nigeria in the period 1986 to 1993. Results of ARIMA 
and OLS estimations indicate that appreciation of exchange rate and its volatility have negative impacts on agricultural export earnings.

By applying OLS on the time series of relevant variables including exchange rate over the annual period of 1970-2005 Abolagba et al. (2010) find that appreciation of real exchange rate has statistically significant and negative impact on export of cocoa and rubber in Nigeria.

Ros (1993) analyzes Mexico's non-oil trade and industrialization experience during 1960-1990 and concludes that appreciation of real exchange rate due to oil revenues is harmful for non-oil export performance.

The influences of trade and exchange rate policies on agricultural export which is the main part of non-oil export of Cameroon is studied by Amin (1996) over the period 1971-1992. Study concludes that current exchange rate policy especially appreciation of national currency impedes agricultural export.

Mohamad et al. (2009) conduct panel data estimation to account for the role of the real exchange rate and other economic fundamentals such as macroeconomic stability, terms of trade, capital goods investment, external demand and human capital on the export performance of Indonesia, Malaysia, Singapore and Thailand. They find that appreciation of real exchange rate and also its misalignment and volatility have strong negative impact on export performance.

By employing Pooled Mean Group over the period of 1970 to 2003 Benbouziane and Benamar (2007) investigate the impact of exchange rate regime on the real sector in some Middle East and North Africa Countries including Algeria, Bahrain, Iran, Kuwait, Libya, Saudi Arabia, and Sudan which are oil rich. Study finds that as a whole, exchange rate overvaluation reduces competitiveness of manufactured goods in these countries.

Egert Balazs and Morales-Zumaquero (2005) estimates export functions both in nominal and real terms in the case of transition countries of Central and Eastern Europe including Russia over the period 1990-2005 by employing panel regression and ARDL modeling. They use domestic and 
foreign income, foreign direct investment, relative prices, the nominal exchange rate for nominal exports, the real exchange rate for real exports, and a volatility measure of the nominal and the real exchange rates respectively as explanatory variables and conclude that in general appreciation of exchange rate (nominal or real terms) and also its volatility are harmful for export earnings.

\section{Data collection, Non-oil Export Equation and Employing methodology}

\subsection{Data collection}

Non-oil export in real terms $(X)$. Since the export price index is unavailable for the entire estimation period, real non-oil exports are calculated as the ratio of nominal non-oil exports to weighted average of the consumer price indices of the main trading partners. The weights correspond to the share of the total trade turnover with the respective country.

The trade turnover based average of the consumer price index of main trade partners $\left(C P I^{F}\right)$ is calculated based on prices and weights of country's main 13 trading partners as below:

$C P I^{F}=\sum_{i=1}^{13} C P I_{i}^{F} \cdot W_{i}$

Where,

$C P I_{i}^{F}-$ is a $C P I i^{\text {th }}$ main trading partner;

$W_{i}-$ is a weight of $i^{\text {th }}$ main trading partner in our overall trade turnover.

Real effective exchange rate $(R E R)$. As a real exchange rate study uses real effective exchange rate.

Non-oil GDP net of non-oil net export in real terms $(Z)$. In order to avoid endogeneity we use non-oil GDP net of non-oil net exports as a control variable. This variable will be called "real nonoil GDP" hereafter. Since the deflator of non-oil GDP is not available we use CPI as a proxy for it. We calculate real values of $\mathrm{Z}$ as below: 
$Z=\frac{\text { Nominal Non oil GDP }- \text { Nominal Non oil Net Export }}{C P I}$

Time series data of all required variables are obtained from the official web page of Central Bank of Azerbaijan.

\subsection{Non-oil Export Equation}

Based on the conventional equations of supply of exports and by following the approach employed by Jongwanich (2007) our non-oil export equation is as below:

$$
X=a_{0}+a_{1}\left(\frac{p^{x}}{\bar{p}^{d}}\right)+a_{2} Z
$$

Where,

$p^{x}-$ is an export price expressed in foreign currency;

$\bar{p}^{d}=\frac{p^{d}}{e} ; p^{d}-$ is a price of exportable in the domestic market expressed in local currency and $e-$ stands for nominal exchange rate (local currency per a unit of foreign currency).

If we replace $\bar{p}^{d}$ with $\frac{p^{d}}{\theta}$ then equation (3) becomes as below:

$$
X=a_{0}+a_{1}\left(\frac{e p^{x}}{p^{d}}\right)+a_{2} Z
$$

It is obvious that $\frac{e p^{x}}{p^{d}}=R E R$ as indicated Tihomir (2004). Note that an increase in $R E R$ means a depreciation of the domestic currency in this definition.

Thus, our final export supply function seems as below:

$X=a_{0}+a_{1} R E R+a_{2} Z$ 


\subsection{Employing methodology}

We estimate the impacts of the real effective exchange rate and real non-oil GDP on non-oil exports in real terms in the long- and short-run. In other words we construct Error Correction Model between variables in interest. In order to estimate co-integration relationship one can use Engle-Granger or Johansen approaches. But it is also emphasized by econometricians that application of Engle-Granger approach is not appropriate in the presence of more than two variables. The point is that Engle-Granger approach intends only one co-integrating equation between variables. But when we have more than two variables, say that three variables then it is possible existence of two co-integrating equation. Since we have three variables it is preferable to apply Johansen's co-integration method.

Thus, in order to test for co-integration we use the Johansen (1988) and Johansen and Juselius (1990) full information maximum likelihood of a Vector Error Correction Model. The model is given as follows:

$$
\Delta y_{t}=\Pi y_{t-1}+\sum_{i=1}^{k-1} \Gamma_{i} \Delta y_{t-i}+\mu+\varepsilon_{t}
$$

Where, $y_{t}$ is a $\left(\begin{array}{lll}n & x & 1\end{array}\right)$ vector of the $n$ variables of interest, i.e. non-oil export in real terms, real effective exchange rate, real non-oil GDP, $\mu$ is a $(n \times 1)$ vector of constants, $\Gamma$ represents a $(n x(k-1))$ matrix of short-run coefficients, $\varepsilon_{t}$ denotes a $(n \times 1)$ vector of white noise residuals, and $\Pi$ is a $(n \times n)$ coefficient matrix. If the matrix $\Pi$ has reduced rank $(0<r<n)$, it can be split into a $(n x r)$ matrix of loading coefficients $\alpha$, and a ( $n \times r)$ matrix of co-integrating vectors $\beta$. The former indicates the importance of the co-integration relationships in the individual equations of the system and of the speed of adjustment to disequilibrium, while the latter represents the long-term equilibrium relationship, so that $\Pi=\alpha \beta^{\prime} . k$ is number of lags, $t$ denotes time and $\Delta$ is a difference operator.

Before estimating co-integrated vector-error correction model, the stochastic properties of the time series are assessed by performing unit-root tests. We are going to employ Augmented Dickey-Fuller 
(1981) and Phillips-Perron (1988) for this purpose. Note that, the Augmented Dickey-Fuller and Phillips-Perron tests maintain the null hypothesis of non-stationarity of the time series.

\section{Estimation issues and interpretation of results}

\subsection{Estimation procedures}

All variables in estimation procedures are in their logarithm expression and denoted with small caps respectively ${ }^{4}$. Estimations cover the quarterly period of 2002Q3-2009Q3.

As stated in the methodological section we first conduct Unit-Root Tests by means of Augmented Dickey-Fuller and Phillips-Perron Tests. The tests results indicate that all variables $(x, r e r, z)$ are non-stationary in levels and stationary in first difference (See: Appendix, Table 2).

After ensuring that all variables are integrated of order one as a next step we moved to Johansen cointegration test procedures. We construct a VAR model of three endogenous variables, i.e. $x, r e r, z$ and include here constant and a dummy variable for the first quarter of $2005^{5}$. Then we seek the appropriate lag-length based on the VAR Lag Length Selection Criteria. Most of these criteria indicate that 4 lags are relevant (See: Appendix, Table 3$)^{6}$. Thus, we estimate VAR with 4 lags and this specification has not any problem in terms of autocorrelation, normality and heteroskedasticity of the residuals as shown from Appendix, Table 4-6. Then we employed co-integration test. Both trace and Trace and Max-Eigenvalue tests indicate that there is one co-integrating equation between variables in four versions as indicated at the Appendix, Table 7. In order to choose appropriate one we estimate co-integration equations in all of these four specifications. The third specification is more relevant in terms of model selection criteria (See: Appendix, Table 8). Thus, co-integrating relationship between the non-oil export in real terms, real effective exchange rate and real non-oil

\footnotetext{
${ }^{4}$ Note that all estimation procedures are performed in E-views 7.0 econometrical package.

${ }^{5}$ Dummy variable is included into VAR in order to capture sharp decrease of non-oil export in the first quarter of 2005 which mainly caused by deterioration of non-oil tradable and increasing in oil sector and starting appreciation of exchange rate.

${ }^{6}$ Although most of the lag selection criteria suggest 4 lags, we also estimate VAR in all lag length from 6 lags to 1 lag and conduct Johansen co-integration analysis. We reveal that the results are more robust and meaningful when we estimate VAR in 4 lags.
} 
GDP is as below (see: Appendix, Table 8 for detailed information):

$x=1.68+1.63 \mathrm{rer}+1.46 z$

As given at the Table 8, column 4 in Appendix since the value and sign of error correction coefficient $(-0.31)$ is as expected (i.e. it is in interval of $(-1 ; 0)$ and statistically significant) we can conclude that there is stable co-integration between non-oil export in real terms, real effective exchange rate and real non-oil GDP. At the same time equation (7) is satisfied in term of autocorrelation, normality and heteroskedasticity of residuals (see: Appendix, Table 8, column 4).

After estimating long-run relationship we are going to examine how growth rates of real non-oil GDP and real effective exchange rate affect non-oil export in real terms in the short-run. For this purpose we estimate error correction model by excluding insignificant variables from the model we get more parsimonious specification as below:

\section{Table 1: Short-run model}

\begin{tabular}{|lrrrr|}
\hline $\begin{array}{l}\text { Dependent Variable: D(X) } \\
\text { Independent Variables }\end{array}$ & Coefficient & Std. Error & t-Statistic & Prob. \\
\hline \hline ECM_JOH(-1) & $\mathbf{- 0 . 2 1 4 5 6 4}$ & 0.080819 & -2.654874 & $\mathbf{0 . 0 1 4 8}$ \\
D(X(-1)) & -0.353289 & 0.111630 & -3.164828 & 0.0047 \\
D(Z(-1)) & -0.519433 & 0.215122 & -2.414597 & 0.0250 \\
D(Z(-4)) & 0.486856 & 0.200447 & 2.428850 & 0.0242 \\
D(RER(-1)) & 4.184019 & 1.227734 & 3.407920 & 0.0026 \\
D(RER(-3)) & 3.894444 & 1.633674 & 2.383857 & 0.0266 \\
D_05Q1 & -1.105419 & 0.272597 & -4.055146 & 0.0006 \\
C & 0.050378 & 0.047895 & 1.051845 & 0.3048 \\
\hline
\end{tabular}

Estimated short-run model is satisfactory in terms of coefficient test; residual test and coefficients stability tests as shown from Table 9-15 and Figure 1in the Appendix.

\subsection{Interpretation of results}

\section{Long-run relationship}

Based on the long-run estimation results we conclude that there is statistically significant cointegration between non-oil export in real terms, the real effective exchange rate, and real non-oil GDP. According to equation (7), one percent appreciation (depreciation) of real effective exchange 
rate leads to $\mathbf{1 . 6 3}$ percent decrease (increase) in non-oil export in real terms. This finding is in line with theory. This text-book relationship is crucial in the case of Azerbaijan due to increasing appreciation of exchange rate. Note that real effective exchange rate has appreciated about two times during the 2004-2008. According to long-run model to keep other factors in constant this appreciation has caused reduction of non-oil export in real terms approximately by $3.26(1.63 * 2)$ times during the 2004-2008. This is quite high appreciation and it mainly sources from huge inflow of oil revenues into country. If we take into account that the real effective exchange rate has appreciating trend since 2004 then we can conclude that it is one of the major factors that impede non-oil export growth. Therefore, policymakers should take this fact into consideration in the non-oil export promotion issues, one of the urgent tasks of strategic economic policy of Azerbaijan Republic.

According to equation (7) keeping other factors in constant, one percent increase in real non-oil GDP causes 1.46 percent raise in non-oil export in real terms. This finding is also consistent with our expectations. It is obvious that volume of export can expand as increase aggregate supply.

\section{Short-run relationship}

According to the short run model real effective exchange rate and real non-oil GDP have statistically significant impact on non-oil export in real term. Ceterius paribus a one percent increasing in real non-oil GDP growth with 4 lags results $\mathbf{0 . 4 9}$ percent raising in non-oil export growth in the short-run. Short-run impacts of real effective exchange rate on non-oil export are 4.18 with 1 lag and $\mathbf{3 . 8 9}$ with 3 lags respectively.

Error correction coefficient indicates that short-run fluctuation between variables in interest adjusts to long-run equilibrium relationship. Exactly saying 21 percent of disequilibrium is corrected to the long-run level within a quarter.

It is worth to note that we should be careful when we interpret our estimation results because of small number of observation. 


\section{Concluding remarks}

We attempted shed light to relationship between real exchange rate and non-oil export, one of the important issues for Azerbaijani economy. Based on estimation outputs we can conclude that real effective exchange rate and real non-oil GDP has statistically significant impact on non-oil export both in the long- and short-run. In other words appreciation of real effective exchange rate has negative effect on non-oil export in real terms while real non-oil GDP has positive impacts. It also revealed that short-run fluctuation can be adjusted towards long-run equilibrium relationship. Longrun elasticities of non-oil export in real terms regarding with real effective exchange rate and real non-oil GDP are $\mathbf{1 . 6 3}$ and $\mathbf{1 . 4 6}$ respectively. Short-run impacts of real effective exchange rate on non-oil export are 4.18 with 1 lag and $\mathbf{3 . 8 9}$ with 3 lags respectively. Error correction term indicates that 21 percent of disequilibrium is corrected toward the long-run level within a quarter.

Findings of this study are consistent with economic theory and also reality of Azerbaijani economy. According to theory in general appreciation of national currency negatively affects export earnings of country. This theoretical hypothesis is crucial in the case of Azerbaijan due to by one hand increasing appreciation of exchange rate which mainly sourced from huge inflow of oil revenues and by the other hand declining share of non-oil export caused by domination of oil sector in overall economy in recent years.

Based on results of the study can be concluded that (a) appreciating exchange rate is one of major factors that impede non-oil export growth; (b) increase in value added of non-oil sector leads to increase in non-oil export earnings.

Since promotion of non-oil export is one of the urgent issues of the strategic economic policy of Azerbaijan Republic then findings of this study may be useful for policymakers. 


\section{References}

Abdulrahman Al-Ali. "Saudi Non-oil Export: The Challenges and Prospect", Presented at the Annual Meeting of Middle East Studies Association of North America (MESA), 22-25 November, 1997.

Abolagba E.O., Onyekwere N.C, Agbonkpolor B.N. and Umar H.Y. ”Determinants of Agricultural Exports" Kamla-Raj J Hum Ecol, 29(3): 181-184. 2010.

Adubi A.A.,Okunmadewa F. "Price, exchange rate volatility and Nigeria's agricultural trade flows: A dynamic analysis", AERC Research Paper 87. March 1999.

Amin A.A. "The Effects of Exchange Rate Policy on Cameroon's Agricultural Competitiveness". AERC Research Paper No. 42. Nairobi: AERC. 1996.

Arize C. Augustine, Malindretos John and Kasibhatla M. Krishna. "Does Exchange-Rate Volatility Depress Export Flows: The Case of LDCs”, IAER: VOL. 9, NO. 1. February 2003.

Athukorala P. "Exchange rate pass-through: The case of Korean exports of manufactures", Economic Letters, 35, 79 D84. 1991.

Athukorala P. and Menon J. "Pricing to market behavior and exchange rate pass-through in Japanese exports", Economic Journal, 104, 271D 81. 1994.

Bayoumi T. "Estimating Trade Equations from Aggregate Bilateral Data" CEPR Discussion Papers. Sep 1998.

Bahmani-Oskooee M. and Kara O. "Relative Responsiveness of Trade Flows to a Change in Prices and Exchange Rate," International Review of Applied Economics 17, 293-308. 2003.

Benbouziane Mohammed and Benamar Abdelhak "The Impact of Exchange Rate Regime On The Real Sector In Mena Countries", 27th Annual Meeting of The Middle East Economic Association (MEEA) Chicago, Illinois, January 4-7, 2007.

Bernardina Algieri "Price and Income Elasticities of Russian Exports" The European Journal of Comparative Economics, Vol. 1, n. 2, 2004, pp. 175-193, ISSN 1824-2979, http://eaces.liuc.it

Corden W.M. "Booming Sector and Dutch Disease Economics: Survey and Consolidation”, Oxford Economic Papers 36, 359-380, 1984.

Corden W.M. and Neary J.P. "Booming Sector and De-Industrialization in a Small Open Economy" Economic Journal 92, 825-848, 1982.

Dickey D. and Fuller W. "Likelihood Ratio Statistics for Autoregressive Time Series with a Unit Root," Econometrica, Vol. 49. 1981.

Dorosh Paul and Valdes Alberto "The Effects of exchange rate and trade policies on agriculture in Pakistan" IFPRI Research Report No. 84. 1990.

Eduardo Levy-Yeyati and Sturzenegger Federico "Classifying Exchange Rate Regimes: Deeds vs. Words” Business School, Universidad Torcuato Di Tella, This version: January 2002.

Egert Balazs and Morales-Zumaquero Amalia "Exchange Rate Regimes, Foreign Exchange Volatility and Export Performance in Central and Eastern Europe" 2005

Elgali B. Mohamed and Mustafa H. Rajaa and Bauer S. "The Impact of Exchange Rate Policy on Sudanese Agriculture", 2006.

Elke H. "The Impact of Exchange Rate Shocks on Sectoral Activity and Prices in the Euro Area”, 2009.

Emilio J. Medina-Smith "Is the export-led growth hypothesis valid for developing countries? A case study of Costa Rica". Policy Issues in International Trade and Commodities. Study series No. 7 United Nations, New York and Geneva, 2001.

Fang W. and Miller S.M. and Lai Y. "Export Promotion through Exchange Rate Policy: Exchange 
Rate Depreciation or Stabilization?” 2005.

Fang WenShwo and Miller Stephen "Exchange rate depreciation and exports: The case of Singapore revisited" Las Vegas, November 2004.

Fosu, Yerfi K. 1992. The Real Exchange Rate and Ghana's Agricultural Exports. AERC Research Paper No. 9. Nairobi: AERC.

Gabriel Di Bella and Mark Lewis and Aurelia Martin "Assessing Competitiveness and Real Exchange Rate Misalignment in Low-Income Countries”, IMF Working Paper, 2007.

Gibson L. and Ward Michael D. "Export Orientation: Pathway or Artifact?" International Studies Quarterly 36.3. p.331-43. 1992.

Goldstein J. and Pevehouse C. International Relations. 8th ed. New York: Pearson Longman, 2008.

Haleem Usman, Mushtaq Khalid, Abbas Azhar, and Sheikh A. D. "Estimation of Export Supply Function for Citrus Fruit in Pakistan” The Pakistan Development Review 44 : 4 Part II pp. 659-672. Winter 2005.

Hasan Vergil "Exchange Rate Volatility in Turkey and Its Effect on Trade Flows", Journal of Economic and Social Research Vol. 4(1), 2002.

Inutu Lukonga "Nigeria's Non-oil Exports: Determinants of supply and demand. 1970-1990”, IMF Working Paper, 1994.

Johansen S. "Likelihood-based inference in cointegrated vector auto-regressive models", Oxford University Press, USA. 1995.

Johansen S. "Statistical analysis of cointegration vectors". Journal of Economic Dynamics and Control 12, 231-254. 1988.

Johansen S. and Juselius K. "Maximum likelihood estimation and inference on cointegration with applications to the demand for money". Oxford Bulletin of Economics and Statistics 52, 169-210. 1990.

Jongwanich Juthathip "Determinants of Export Performance in East and Southeast Asia" ERD Working Paper Series no. 106, November 2007

Junz H. and Rhomberg R. "Price Competitiveness in Export Trade among Industrial Countries," American Economic Review, Papers and Proceedings 63, 412-418. 1973.

Juselius K. "The cointegrated VAR model: methodology and applications", Oxford University Press Inc., New York. 2006.

Kidane Asmerom "Real Exchange Rate Price and Agricultural Supply Response in Ethiopia: The Case of Perennial Crops" African Economic Research Consortium, November 1999

Kolawole Olayiwola, Henry Okodua "Foreign Direct Investment, Non-Oil Exports, and Economic Growth in Nigeria: A Causality Analysis", Department of Economics and Development Studies Covenant University, Ota, Nigeria.

Levin A. and Lin C. F. and C.S. J. Chu "Unit Root Tests in Panel Data: Asymptotic and FiniteSample Properties" Journal of Econometrics 108, 2002.

Masoud Homayounifar and Rastegari Fatemeh "Analysis of Economic-Political Factors Affecting non Oil Export of Iran”, IDOSI Publications. 2008.

McCombie J.S.L. and Thirlwall A.P. "Economic Growth and the Balance-of-Payments Constraint". New York: St. Martin's, 1994.

Mohamad Saadiah and Nair Mahendhiran and Jusoff Kamaruzaman "Exchange Rates and Export Competitiveness in Selected ASEAN Economies" International Business Research, Vol, 2. No.2, 2009

Mohammad B. and Naser S. "Causality between non-oil exports and GDP growths in Iran”, 2008.

Niemi Jyrki "Cointegration and error correction modeling of agricultural commodity trade: The case of 
ASEAN agricultural exports to the EU" MTT Agrifood Research Finland, Economic Research. 2003.

Oyejide, T. A. "The Effects of trade and exchange rate policies on agriculture in Nigeria" IFPRI Research Report No. 55. 1986.

Ogun Oluremi "Real exchange rate movements and export growth: Nigeria, 1960- 1990" African Economic Research Consortium, November 1998

Pesaran M. Hashem and Shin Yongcheol and Smith P. Ron "Pooled Mean Group Estimation of Dynamic Heterogeneous Panels" Journal of the American Statistical Association, Vol. 94, No. 446, pp. 621-634, Published by: American Statistical Association. Jun., 1999

Phillips P.C.B. and Perron P. "Testing for a Unit Root in Time Series Regression”, Biometrika, Vol. 75, 335-46. 1988.

Przemek Kowalski, Wojciech Paczynski, Lukasz Rawdanowicz. "The choice of exchange rate regime and the real sector. What can we learn from the experience of transition economies?", CERGE research project No. 65/2002 Non-technical summary, June 2003.

Rafayet Alam "The Link between Real Exchange Rate and Export Earning: A Cointegration and Granger Causality Analysis on Bangladesh", International Review of Business Research Papers Vol.6, No.1 February 2010.

Ros Jaime "Mexico's trade and industrialization experience since 1960: a reconsideration of past policies and assessment of current reforms" working paper \#186 - january 1993

Rose Andrew K. "Exchange Rates and the Trade Balance." Economics Letters 34: 271-5. No. 2. 1990.

Sabuhi-Sabouni M. and Piri M. "Consideration the Effect of Exchange Rate Volatility on Agricultural Products Export Price, the Case Study of Iran's Saffron,” IDOSI Publications, 2008.

Safiu Olukayode Olaniyan "Determinants of Non-Oil Exports in Nigeria", African Institute for Economic Development and Planning, 2004.

Sangita P. "Determinants of Exports in Fiji”, Economics Department Reserve Bank of Fiji, June 2000.

Seyed Javad Pourmoghim “The Optimal Level of Non-oil Exports: A Theoretical Proposal of Iran's Case”, Iranian Economic Review, Vol.9, No.10, Spring 2004.

Smith Mark "Impact of the exchange rate on export volumes" Economics Department, Reserve Bank of New Zealand: Bulletin vol. 67 No. 1.2004.

Sorsa Piritta “Algeria-The Real Exchange Rate, Export Diversification, and Trade Protection". Policy Development and Review Department, International Monetary Fund. April 1999

Suut D., Fatma D., Umit I. "The Impact of Exchange Rate Regime on the Real Sector in MENA Countries" 30th Annual Meetings of the Middle East Economic Association January 3, 6, Atlanta. 2010.

Tihomir Stucka "The Effects of Exchange Rate Change on the Trade Balance in Croatia" IMF Working Paper, WP/04/65, April 2004

Wilson P. and Tat K. C. "Exchange rates and the trade balance: the case of Singapore 1970 to 1996," Journal of Asian Economics 12, 47-63. 2001.

Wang Kai-Li and Barrett B. Christopher "A New Look At the Trade Volume Effects of Real Exchange Rate Risk", November 2002.

Yusuf Adesina S. and Edom Cyprian O. "Determinants of timber exports in Nigeria: an error correction modeling approach", Department of Agricultural Economics, University of Ibadan, Nigeria, 2007.

Yusuf S.A. and Yusuf W.A. "Determinants of Selected Agricultural Export Crops in Nigeria: An ECM Approach” AAAE Conference proceedings: 469-472. 2007. 
Table 2: Results of Unit Root Tests

\begin{tabular}{|c|c|c|c|c|c|c|c|}
\hline \multirow{2}{*}{ Variables } & \multirow{2}{*}{ Test Method } & \multicolumn{3}{|c|}{ In the level } & \multicolumn{3}{|c|}{ In the first difference } \\
\hline & & Constant & Trend & Actual value & Constant & Trend & Actual value \\
\hline \multirow{2}{*}{$\mathbf{x}$} & $A D F$ & No & No & 0.144550 & No & No & $-5.609120 * * *$ \\
\hline & $P P$ & No & No & 0.340709 & No & No & $-19.07625 * * *$ \\
\hline \multirow{2}{*}{$\mathbf{z}$} & $A D F$ & Yes & Yes & -2.958867 & Yes & No & $-7.302980 * * *$ \\
\hline & $P P$ & Yes & Yes & -4.475187 & No & No & $-5.320252 * * *$ \\
\hline \multirow{2}{*}{ rer } & $A D F$ & Yes & Yes & -1.786916 & No & No & $-3.576087 * * *$ \\
\hline & $P P$ & Yes & Yes & -2.012322 & No & No & $-3.576087 * * *$ \\
\hline
\end{tabular}

Table 3: Lag Order Selection

\begin{tabular}{|c|c|c|c|c|c|c|}
\hline \multicolumn{2}{|c|}{ Endogenous variables: X RER Z } & \multicolumn{5}{|c|}{ Exogenous variables: C D_05Q1 } \\
\hline Lag & $\log L$ & LR & FPE & AIC & SC & HQ \\
\hline 0 & -0.632030 & NA & 0.000323 & 0.473716 & 0.759189 & 0.560988 \\
\hline 1 & 64.20216 & 106.5133 & $6.04 \mathrm{e}-06$ & -3.514440 & -2.800759 & -3.296260 \\
\hline 2 & 71.59215 & 10.55713 & $7.04 \mathrm{e}-06$ & -3.399439 & -2.257550 & -3.050352 \\
\hline 3 & 88.94377 & 21.06982 & $4.22 \mathrm{e}-06$ & -3.995984 & -2.425885 & -3.515989 \\
\hline 4 & 113.0624 & 24.11858* & $1.69 \mathrm{e}-06 *$ & -5.075883 & $-3.077576 *$ & $-4.464980 *$ \\
\hline 5 & 122.8502 & 7.690447 & $2.12 \mathrm{e}-06$ & -5.132157 & -2.705642 & -4.390347 \\
\hline 6 & 131.9543 & 5.202322 & $3.50 \mathrm{e}-06$ & $-5.139590^{*}$ & -2.284866 & -4.266872 \\
\hline $\begin{array}{l}\text { * indica } \\
\text { LR: seq } \\
\text { AIC: Ak }\end{array}$ & $\begin{array}{l}\text { order selec } \\
\text { modified L } \\
\text { fformation }\end{array}$ & he criterion & formation & on $\mathrm{HQ}: \mathrm{H}_{\mathrm{c}}$ & error & \\
\hline
\end{tabular}

Table 4: VAR Residual Normality Tests

\begin{tabular}{|cc|}
\hline Jarque-Bera & Prob. \\
1.966409 & 0.9228 \\
\hline
\end{tabular}

Table 5: VAR Residual Heteroskedasticity Tests

\begin{tabular}{|ccc|}
\hline Joint test: & & \\
\hline Chi-sq & df & Prob. \\
\hline 155.4630 & 150 & 0.3632 \\
\hline
\end{tabular}

Table 6: VAR Residual Serial Correlation LM Tests

\begin{tabular}{|ccc|}
\hline Lags & LM-Stat & Prob \\
\hline 1 & 10.30502 & 0.3264 \\
2 & 7.220995 & 0.6141 \\
3 & 13.79078 & 0.1300 \\
4 & 14.02453 & 0.1215 \\
5 & 3.668747 & 0.9318 \\
6 & 4.474145 & 0.8775 \\
7 & 8.513759 & 0.4833 \\
8 & 1.481909 & 0.9973 \\
9 & 10.01687 & 0.3491 \\
10 & 3.727200 & 0.9284 \\
11 & 4.025927 & 0.9097 \\
12 & 16.85991 & 0.0510 \\
\hline
\end{tabular}


Table 7: Co-integration Tests

Series: $\mathrm{x}$ rer z; Exogenous series: D_05Q1; Lags interval: 1 to 4

Selected $(0.05$ level*) Number of Cointegrating Relations by Model

\begin{tabular}{|cccccc|}
\hline \hline Data Trend: & None & None & Linear & Linear & Quadratic \\
\hline Test Type & No Intercept & Intercept & Intercept & Intercept & Intercept \\
& No Trend & No Trend & No Trend & Trend & Trend \\
Trace & 1 & 1 & 1 & 1 & 0 \\
Max-Eig & 1 & 1 & 1 & 1 & 0 \\
\hline \hline \multirow{2}{*}{ * Critical values based on MacKinnon-Haug-Michelis (1999) } \\
\hline
\end{tabular}

Table 8: Co-integration Equations Specifications and Residuals Tests

\begin{tabular}{|c|c|c|c|c|}
\hline & \multicolumn{4}{|c|}{ Co-integration Equations Specifications } \\
\hline & $\begin{array}{c}\text { No intercept or } \\
\text { trend in CE or } \\
\text { VAR }\end{array}$ & $\begin{array}{l}\text { Intercept (no trend) } \\
\text { in CE-no intercept } \\
\text { in VAR }\end{array}$ & $\begin{array}{c}\text { Intercept (no } \\
\text { trend) in CE and } \\
\text { VAR }\end{array}$ & $\begin{array}{l}\text { Intercept and } \\
\text { trend in CE-no } \\
\text { trend in VAR }\end{array}$ \\
\hline$x$ & 1.00000 & 1.00000 & 1.00000 & 1.00000 \\
\hline $\begin{array}{l}\text { rer } \\
\text { t-statistics: }\end{array}$ & $\begin{array}{r}1.393211 \\
{[-3.24841]}\end{array}$ & $\begin{array}{r}1.491799 \\
{[2.33425]}\end{array}$ & $\begin{array}{c}1.631752 \\
{[2.36360]}\end{array}$ & $\begin{array}{l}-0.262 .464 \\
{[-0.12553]}\end{array}$ \\
\hline $\begin{array}{l}z \\
\text { t-statistics: }\end{array}$ & $\begin{array}{r}1.656770 \\
{[-6.38877]} \\
\end{array}$ & $\begin{array}{l}1.388 .286 \\
{[5.16244]}\end{array}$ & $\begin{array}{r}1.461850 \\
{[5.03225]} \\
\end{array}$ & $\begin{array}{l}-0.503 .368 \\
{[-0.24603]}\end{array}$ \\
\hline $\begin{array}{l}\text { C } \\
\text { t-statistics: }\end{array}$ & & $\begin{array}{l}2.357456 \\
{[0.69515]}\end{array}$ & 1.678 .826 & 6.093795 \\
\hline $\begin{array}{l}\text { @trend } \\
\text { t-statistics: }\end{array}$ & & & & $\begin{array}{l}0.111904 \\
{[0.89282]} \\
\end{array}$ \\
\hline $\begin{array}{l}\text { ECM coefficient } \\
\text { t-statistics: }\end{array}$ & $\begin{array}{r}-0.314243 \\
{[-3.93039]}\end{array}$ & $\begin{array}{r}-0.35355 \\
{[-3.86026]}\end{array}$ & $\begin{array}{l}-0.307095 \\
{[-3.24051]}\end{array}$ & $\begin{array}{l}-0.315569 \\
{[-2.93514]}\end{array}$ \\
\hline \multicolumn{5}{|c|}{ Statistical Properties } \\
\hline R-squared & 0.929911 & 0.928631 & 0.931315 & 0.925588 \\
\hline Sum squared residuals & 0.364519 & 0.37118 & 0.357218 & 0.387006 \\
\hline Log Likelihood & 22.30961 & 22.04708 & 22.60301 & 21.44165 \\
\hline Akaike AIC & -0.573077 & -0.554971 & -0.524346 & -0.444252 \\
\hline Schwarz SC & -0.086997 & 0.105103 & 0.182876 & 0.26297 \\
\hline \multicolumn{5}{|c|}{ Residuals Tests } \\
\hline LM Test & $\mathrm{OK}$ & $\mathrm{OK}$ & $\mathrm{OK}$ & $\mathrm{OK}$ \\
\hline Jarque-Bera & 2.090579 & 1.873939 & 1.624069 & 1.916626 \\
\hline Prob. & 0.9112 & 0.9309 & 0.9508 & 0.9272 \\
\hline White Heterosk. Test (Chi-sq) & 169.1228 & 169.1684 & 166.8467 & 165.6696 \\
\hline Prob. & 0.3347 & 0.3338 & 0.3807 & 0.4054 \\
\hline
\end{tabular}

Table 9: Short-run estimation output

\begin{tabular}{|lrcrr|}
\hline Dependent Variable: D(X) & \multicolumn{4}{c|}{ Method: Least Squares } \\
\hline Independent Variables & Coefficient & Std. Error & t-Statistic & Prob. \\
\hline ECM_JOH(-1) & -0.214564 & 0.080819 & -2.654874 & 0.0148 \\
D(X(-1)) & -0.353289 & 0.111630 & -3.164828 & 0.0047 \\
D(Z_(-1)) & -0.519433 & 0.215122 & -2.414597 & 0.0250 \\
D(Z_(-4)) & 0.486856 & 0.200447 & 2.428850 & 0.0242 \\
D(RER(-1)) & 4.184019 & 1.227734 & 3.407920 & 0.0026 \\
D(RER(-3)) & 3.894444 & 1.633674 & 2.383857 & 0.0266 \\
D_05Q1 & -1.105419 & 0.272597 & -4.055146 & 0.0006 \\
C & 0.050378 & 0.047895 & 1.051845 & 0.3048 \\
\hline R-squared & 0.808480 & Mean dependent var & 0.012414 \\
Adjusted R-squared & 0.744640 & S.D. dependent var & 0.430980 \\
S.E. of regression & 0.217788 & Akaike info criterion & 0.018360 \\
Sum squared resid & 0.996063 & Schwarz criterion & 0.395545 \\
Log likelihood & 7.733775 & Hannan-Quinn criter. & 0.136490 \\
F-statistic & 12.66413 & Durbin-Watson stat & 2.331871 \\
Prob(F-statistic) & 0.000003 & & \\
\hline
\end{tabular}


Table 10: Residuals Autocorrelation Test of Short-run Model

\begin{tabular}{|c|c|c|c|c|c|c|}
\hline Autocorrelation & Partial Correlation & & $\mathrm{AC}$ & PAC & Q-Stat & Prob \\
\hline$* * \mid$ &.$*$ & 1 & -0.197 & -0.197 & 1.2461 & 0.264 \\
\hline * * . & **1. & 2 & -0.195 & -0.244 & 2.5157 & 0.284 \\
\hline$*$ & $. * * \mid$ & 3 & -0.139 & -0.259 & 3.1803 & 0.365 \\
\hline$\left.\right|^{*}$ & $\cdot|\cdot|$ & 4 & 0.119 & -0.041 & 3.6887 & 0.450 \\
\hline$\cdot 1 \cdot 1$ & $\cdot * 1.1$ & 5 & -0.038 & -0.125 & 3.7427 & 0.587 \\
\hline .1 .1 & .1. & 6 & 0.053 & -0.001 & 3.8533 & 0.697 \\
\hline * * . | & $\cdot *|\cdot|$ & 7 & -0.077 & -0.087 & 4.0974 & 0.768 \\
\hline$\cdot 1 \cdot 1$ &.$|\cdot|$ & 8 & 0.072 & 0.027 & 4.3163 & 0.828 \\
\hline$\cdot * 1.1$ &.$* *|\cdot|$ & 9 & -0.185 & -0.210 & 5.8591 & 0.754 \\
\hline$\cdot|\cdot|$ & * * . & 10 & -0.041 & -0.199 & 5.9369 & 0.821 \\
\hline$\cdot|* *|$. & $\left.\cdot\right|^{*}$. & 11 & 0.265 & 0.153 & 9.4390 & 0.581 \\
\hline$\cdot|\cdot|$ & .1. & 12 & 0.039 & 0.029 & 9.5202 & 0.658 \\
\hline
\end{tabular}

Table 11: Residuals Normality Test of Short-run Model

\begin{tabular}{|cc|}
\hline Jarque-Bera & Prob. \\
1.8944 & 0.3878 \\
\hline
\end{tabular}

Table 12: Residuals Serial Correlation Test of Short-run Model

\begin{tabular}{|c|c|c|c|}
\hline \multicolumn{4}{|c|}{ Breusch-Godfrey Serial Correlation LM Test: } \\
\hline F-statistic & 1.714244 & Prob. F(2,19) & 0.2068 \\
\hline Obs*R-squared & 4.433029 & Prob. Chi-Square(2) & 0.1090 \\
\hline
\end{tabular}

Table 13: Residuals ARCH Heteroskedasticity Test of Short-run Model

\begin{tabular}{|c|c|c|c|}
\hline F-statistic & 0.436031 & Prob. F $(1,26)$ & 0.5149 \\
\hline Obs*R-squared & 0.461827 & Prob. Chi-Square(1) & 0.4968 \\
\hline
\end{tabular}

Table 14: Residuals White Heteroskedasticity Test of Short-run Model

\begin{tabular}{|llll|}
\hline F-statistic & 1.437604 & Prob. F(7,21) & 0.2430 \\
Obs*R-squared & 9.394824 & Prob. Chi-Square(7) & 0.2255 \\
Scaled explained SS & 2.843943 & Prob. Chi-Square(7) & 0.8991 \\
\hline
\end{tabular}

Table 15: Ramsey Reset Test of Short-run Model

\begin{tabular}{|llll|}
\hline F-statistic & 0.585630 & Prob. F(1,20) & 0.4531 \\
Log likelihood ratio & 0.836968 & Prob. Chi-Square(1) & 0.3603 \\
\hline
\end{tabular}

Figure 1: Parameters Stability Tests of Short-run Model
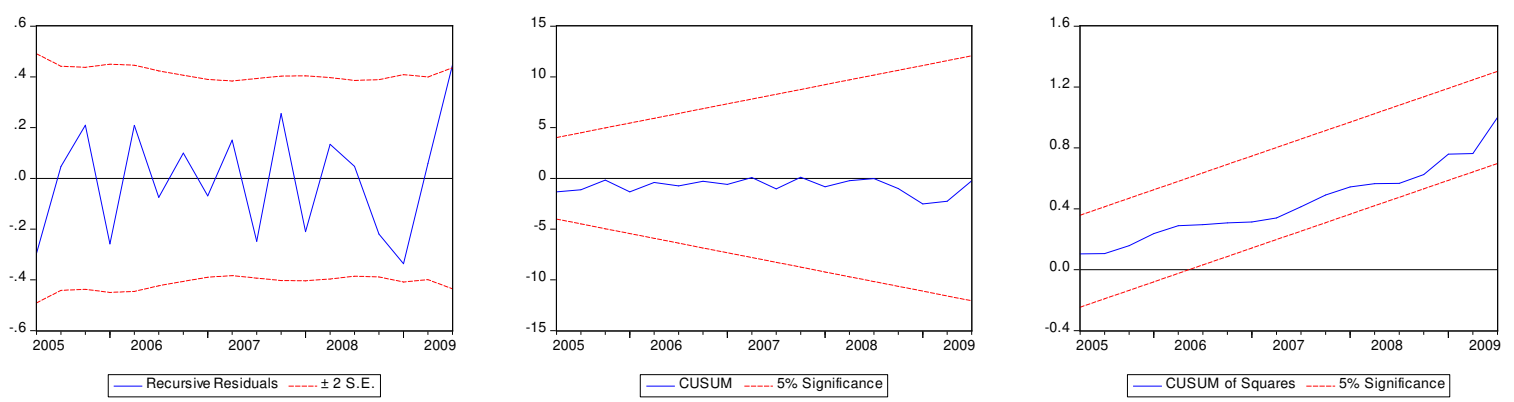